\title{
Pengaruh Media Film Animasi Terhadap Motivasi Belajar Siswa Mata Pelajaran IPA(Studi Penelitian di MI AN-NUR Kota Cirebon)
}

\author{
Mukhlishoh, Iis Khisbiyah
}

\begin{abstract}
Abstrak
Pentingnya kegiatan teknologis dalam pengelolaan tersebut dimakasudkan agar dapat membantu proses pembelajaran dalam mencapai tujuan pendidikan, Namun, pada saat ini banyak siswa yang belum menunjukkan motivasinya dalam belajar dikarenakan proses pembelajaran yang membosankan tanpa adanya media yang baru. Salah satu media teknologi dalam pembelajaran adalah media film animasi, media film animasi merupakan media berupa gambar yang bergerak disertai dengan suara dan merupakan perkembangan dari IPTEK. Dengan penggunaan media film animasi ini terdapat pengaruh bagi siswa itu sendiri dalam proses belajarnya seperti meningkatnya motivasi belajar siswa. Penelitian ini merupakan penelitian kuantitatif dengan teknik pengumpulan data berupa angket dan observasi. Populasi dalam penelitian ini adalah semua siswa kelas V.2 MI An-Nur Kota Cirebon sebanyak 28 siswa dan menggunakan sampel total sampling yaitu kelas V sebanyak 28 siswa. Dari hasil pengolahan data tersebut didapat kesimpulan bahwa rata - rata nilai angket media film animasi di MI An-Nur kota Cirebon sebesar $84 \%$ dan motivasi belajar IPA diperoleh rata - rata persentase yang menjawab 5(sangat setuju) sebesar $42 \%$, menjawab 4(setuju) sebesar 36,5\% jadi jumlahnya adalah 78,5\%. Adapun hasil uji regresi menggunakan Analisis Model Summary ${ }^{b}$ pengaruh media film animasi dapat menggunakan angka R Square (koefisien determinasi) 0,246 x $100=24,6 \%$. Angka tersebut memiliki arti bahwa sebesar $24,6 \%$ variabelitas motivasi belajar dipengaruhi oleh variable media film animasi. Dan sisanya sebesar $100-24,6=75,4 \%$ harus dijelaskan oleh faktor faktor lainya yang berasal dari luar model regresi ini. Berdasarkan tabel analisis anova b didapat nilai Sig sebesar 0,007 Karena lebih kecil 0,05 maka $\mathrm{H} 0$ ditolak dan Ha diterima maka terdapat hubungan linier antara variable pengaruh media film animasi dan motivasi belajar siswa di MI AN-NUR Kota Cirebon.
\end{abstract}

\section{A. Pendahuluan}

Tujuan mata pelajaran IPA adalah membangun masyarakat melek sains. "Melek sains" dimaksudkan sadar terhadap perkembangan dunia informasi, teknologi, dan peradaban manusia secara menyeluruh sesuai dengan kemajuan dunia. Orang yang "melek sains" tidak akan alergi dengan perubahan, karena perubahan adalah sunatullah. Tetapi kenyataannya masarakat kita masih takut dengan 
perubahan. Perubahan menuntut resiko dan tanggung jawab. Orang yang sadar terhadap perkembangan dunia tidak akan tinggal diam, tetapi selalu menyesuaikan diri dengan meningkatkan kemampuan diri.

Supaya orang melek informasi dan teknologi, tentu diawali dengan cara mengajar yang mendukung kearah itu. Salah satunya pernah diungkapkan oleh UNESCO (disebut juga empat pilar pendidikan) tentang pengajaran ini menuntut kompetensi yang mendekati komprehensif. Lembaga ini menyarankan perlunya penekanan kepada empat paradigm pembelajaran yaitu: learning to know, learning to do, learning to be, dan learning to live together. Pengajaran ini dipandang sempurna pada zamannya, bahkan sampai saat ini orang masih meyakini bahwa prinsip ini baik dan perlu dilakukan.

Learning to know merupakan prinsip bahwa belajar adalah untuk mengetahui atau memahami. Dengan prinsip ini pembelajaran harus dikondisikan agar murid aktif dan menciptakan suasana untuk selalu ingin mengetahui dan memahami sesuatu yang baru. Dengan demikian pembelajaran hendaknya menciptakan sikap "penasaran" pada murid, sehingga murid selalu ingin belajar lebih jauh.

Learning to do adalah merupakan prinsip belajar untuk megerjakan sesuatu. Prinsip ini mewujudkan bahwa dalam belajar bukan hanya untuk sekedar mengetahui, tetapi juga mampu melaksanakan atau mempraktekkan. Dengan prinsip ini ada keserasian dan keseimbangan antara teori dan praktek, seperti pendidikan jasmani wajib dilakukan praktek, begitu juga dengan mata pelajaran yang berisi teori seperti IPA, hal itu harus dilakukan berimbang.

Learning to be adalah prinsip belajar untuk mencapai sesuatu. Prinsip ini mengarahkan murid untuk selalu bekerja keras untuk mencapai sesuatu dan tidak putus asa. Dengan demikian murid memiliki pandangan dan bekerja keras, karena dalam dirinya akan muncul perjuangan dalam mencapai sesuatu. Dengan prinsip ini murid memilki cita-cita dan pandangan jauh kedepan.

Learning to live together adalah prinsip belajar untuk hidup bersama. Murid merupakan bagaian darisebuah sistem, komunitas, dan masyarakat. Dalam 
pembelajaran harus dihindari situasi eksklusifitas pada diri murid. Sebagai bagian dari suatu sistem, maka aturan-aturab harus diterapkan terhadap murid, seperti kedisiplinan dan kerja sama. Murid merupakan bagian dari komunitas, bahwa murid belajar bersama guru dan murid lain. Untuk itu dalam pembelajaran hendaknya diciptakan suasana kerjasama dan saling menghargai antara murid yang satu dengan murid yang lainnya. Sekolah merupakan tempat bagi murid untuk mempersiapkan diri untuk hidup di masyarakat, karena murid merupakan bagain dari masyarakat. Dengan kata lain, pembelajaran dengan prinsip ini mengkondisikan murid sebagai bagian dari sebuah sistem belajar untuk berorganisasi dan hidup bersama. (Wahidin, 2006:19)

Pada era yang serba teknologi seperti ini Negara di dunia dalam segala aktifitasnya selalu mengaitkannya dengan teknologi, baik bidang ekonomi, industri, pertanian bahkan dalam pendidikan, dengan teknologi pekerjaan manusia akan lebih mudah. Revolusi ilmu pengetahuan dan teknologi, perubahan masyarakat, pemahaman cara belajar anak, kemajuan media komunikasi dan informasi dan lain sebagainya memberi arti tersendiri bagi kegiatan pendidikan. Tantangan tersebut menjadi salah satu dasar pentingnya kegiatan teknologis dalam pengelolaan pembelajaran. Pentingnya kegiatan teknologis dalam pengelolaan tersebut dimakasudkan agar dapat membantu proses pembelajaran dalam mencapai tujuan pendidikan, yakni al-insan al-kamil(Yudhi Munadi:2010).

Teknologi pembelajaran merupakan suatu hal yang harus dalam pendidikan jika negara kita ini tidak ingin ketinggalan dengan negara-negara lain dalam bidang pendidikan. Salah satu wujud dari teknologi pembelajaran adalah dengan adanya internet, alat-alat penunjang pembelajaran seperti laptop, infokus, spiker aktif sangat dibutuhkan dalam mewujudkan suatu teknologi pembelajaran yang modern.

Sudah selayakya lembaga-lembaga pendidikan yang ada segera memperkenalkan dan mulai menggunakan teknologi informasi dan komunikasi (TIK) sebagai basis pembelajaran yang lebih mutahir. Hal ini penting, mengingat penggunaan TIK merupakan salah satu faktor penting yang memungkinkan kecepatan transformasi ilmu pengetahuan kepada para peserta didik, generasi bangsa ini secara lebih luas. Dalam konteks yang lebih spesifik, dapat dikatakan bahwa kebijakan penyelenggaraan pendidikan, baik yang diselenggarakan oleh pemerintah, pemerintah daerah, maupun masyarakat harus mampu memberikan akses pemahaman dan penguasaan teknologi mutahir yang luas kepada para peserta didik (Deni Dermawan:2011). 
Penggunaan media atau alat bantu disadari oleh banyak praktisi pendidikan sangat membantu aktivitas proses pembelajaran. Dengan menggunakan media salah satunya adalah media film animasi pembelajaran dapat dijadikan sebagai perangkat ajar yang siap kapan pun digunakan untuk menyampaikan materi pelajaran selain itu juga dengan media film animasi seorang guru dapat menampilkan simulasi dengan sangat mudah seperti simulasi proses terjadinya hujan, dengan adanya media proses pembelajaran akan lebih menarik dan tentunya para siswa akan lebih termotivasi untuk mengikuti pembelajaran IPA dengan serius.

Namun, pada saat ini media pembelajaran yang berbasis teknologi seperti media film animasi masih jarang digunakan dalam pembelajaran di kelas sehingga banyak siswa yang belum menunjukkan motivasinya dalam belajar, mereka hanya ingin bermain bersama teman-temannya.(Data diperoleh dari hasil observasi di Madrasah Ibtidaiyah An-Nur kota Cirebon pada tanggal 12 februari 2015)

Oleh sebab itu, perlu diadakan penelitian tentang Pengaruh Media Film Animasi Terhadap Motivasi Belajar Siswa Mata Pelajaran IPA, kemudian diseminarkan untuk para guru di sekolah.

Pembatasan Masalah

1. Lokasi penelitian di Madrasah IbtidaiyahAn-Nur Kota Cirebon.

2. Variabel penelitian media film animasi dan motivasi belajar siswa mata pelajaran IPA.

3. Penelitian ini dilakukan pada siswa kelas 5 (2) MI An-Nur Kota Cirebon.

Rumusan Masalah

Berdasarkan latar belakang permasalahan di atas dapat ditarik kesimpulan, betapa pentingnya teknologi dalam pembelajaran dan sejauh mana pengaruhmedia film animasi dalam pembelajaran IPA. Sehingga dengan demikian akan memunculkan rumusan masalah sebagai berikut :

1. Bagaimana proses penerapan media film animasi dalam pembelajaran IPA di MI An-Nur?

2. Bagaimana motivasi belajar siswa pada mata pelajaran IPA di MI An-Nur? 
3. Bagaimana pengaruh media film animasi terhadap motivasi belajar siswa pada mata pelajaran IPA di MI An-Nur?

Tujuan Penelitian

Setiap kegiatan sehari-hari dapat dipastikan memiliki tujuan tertentu, begitu pula dalam kegiatan penelitian ilmiah ini tak akan lepas dari tujuan yang telah digariskan, sebab pada dasarnya tujuan ini banyak memberikan warna atau arahan pelaksanaan tujuan itu sendiri yang mengacu pada rumusan masalah yang telah ditetapkan, oleh karena itu tujuan penelitian ini dapat dikemukakan sebagai berikut ;

1. Untuk mengetahui proses penerapan media film animasi dalam pembelajaran IPA di MI An-Nur.

2. Untuk mengetahui data tentang motivasi belajar siswa di di MI An-Nur

3. Untuk mengetahui pengaruh media film animasi terhadap motivasi belajar siswa pada mata pelajaran IPA di MI An-Nur

\section{B. Penggunaan Media Film Animasi dalam Pembelajaran IPA di MI An-Nur kota Cirebon}

Seperti yang telah dijelaskan media pada dasarnya adalah bahasanya guru artinya dalam proses penyampaian pesan pembelajaran, guru harus pandai memilih bahasa apa yang paling mudah dimengerti dan dipahami siswanya. Dengan gambar yang bergerak atau film animasi dianggap sesuai dengan karakteristik siswa MI dan akan meningkatkan motivasi belajar siswa dalam mata pelajaran IPA.

Hal ini sesuai dengan pendapat Ngalim Purwanto (2007:72) dalam bukunya Psikologi Pendidikan menyebutkan bahwa: Menurut Vroom, motivasi mengacu kepada suatu proses mempengaruhi pilihan-pilihan individu terhadap bermacammacam bentuk kegiatan yang dikehendaki.

Berdasarkan hasil observasi yang telah dilakukan kinerja guru dalam menggunakan media film animasi dalam pembelajaran IPA, didapatkan nilai16. Yang berarti secara garis besar guru sudah sangat baik dalam menggunakan media film 
animasi dalam pembelajaran IPA.Namun, terdapat beberapa kekurangan dalam hal keterampilan dalam penggunaan media film animasi.

\section{One-Sample Kolmogorov-Smirnov Test}

\begin{tabular}{|c|c|c|c|}
\hline & & Media_film_Animasi & Motivasi_Belajar \\
\hline $\mathrm{N}$ & & 28 & 28 \\
\hline \multirow{2}{*}{ Normal Parameters ${ }^{\mathrm{a}, \mathrm{b}}$} & Mean & 42.14 & 41.14 \\
\hline & Std. Deviation & 7.382 & 4.300 \\
\hline \multirow{3}{*}{ Most Extreme Differences } & Absolute & .329 & .181 \\
\hline & Positive & .144 & .150 \\
\hline & Negative & -.329 & -.181 \\
\hline Kolmogorov-Smirnov Z & & 1.742 & .950 \\
\hline Asymp. Sig. (2-tailed) & & .005 & .317 \\
\hline
\end{tabular}
a. Test distribution is Normal.
b. Calculated from data.

Berdasarkan uji normalitas media film animasi One-Sample KolmogorovSmirnov Test, didapatkan nilai kolmogorov smirnov $Z$ adalah nilai 1.742, karena nilai yang didapat melebihi nilai 0.05 , maka nilai signifikansinya normal. Dikarenakan memiliki nilai signifikansi yang normal, berarti respon siswa terhadap Media film animasi berasal dari popolasi berdistribusi normal.

\section{Rekapitulasi Prosentase Perhitungan Angket Media Film Animasi}

\begin{tabular}{|c|c|c|c|}
\hline \multirow{2}{*}{ No Item } & \multicolumn{2}{|c|}{ OPTION } & \multirow{2}{*}{ JUMLAH } \\
\cline { 2 - 3 } & SETUJU & TIDAK SETUJU & \\
\hline 1 & $68 \%$ & $32 \%$ & $100 \%$ \\
\hline
\end{tabular}




\begin{tabular}{|c|c|c|c|}
\hline 2 & $89 \%$ & $11 \%$ & $100 \%$ \\
\hline 3 & $89 \%$ & $11 \%$ & $100 \%$ \\
\hline 4 & $89 \%$ & $11 \%$ & $100 \%$ \\
\hline 5 & $93 \%$ & $7 \%$ & $100 \%$ \\
\hline 6 & $79 \%$ & $21 \%$ & $100 \%$ \\
\hline 7 & $82 \%$ & $18 \%$ & $100 \%$ \\
\hline 8 & $71 \%$ & $29 \%$ & $100 \%$ \\
\hline 9 & $96 \%$ & $4 \%$ & $100 \%$ \\
\hline 10 & $86 \%$ & $14 \%$ & $100 \%$ \\
\hline Jumlah & $842 / 10$ & $158 / 10$ & $1000 / 10$ \\
\hline Rata -Rata & $84 \%$ & $16 \%$ & $100 \%$ \\
\hline
\end{tabular}

Berdasarkan perhitungan angket media film animasi dalam pebelajaran IPA rata-rata siswa yang menjawab setuju sebanyak 84\%. Hal ini membuktikan optimalnya penggunaan media film animasi dalam pembelajara IPA di kelas V MI An-Nur Kota Cirebon.

\section{Motivasi Belajar Siswa Pada Mata Pelajaran IPA di MI An-Nur Kota Cirebon}

Dalam pembelajaran, motivasi adalah sesuatu yang menggerakkan atau mendorong siswa untuk belajar atau menguasai materi pelajaran yang sedang diikutinya. (Gintings : 87) Tanpa motivasi, siswa tidak akan tertarik dan serius dalam mengikuti pembelajaran. Sebaliknya, dengan adanya motivasi yang tinggi, siswa akan tertarik dan terlibat aktif bahkan berinisiatif dalam proses pembelajaran. Dengan 
motivasi yang tinggi siswa akan berupaya sekuat-kuatnya dan dengan menempuh berbagai strategi yang positif untuk mencapai keberhasilan dalam belajar.

One-Sample Kolmogorov-Smirnov Test

\begin{tabular}{|ll|r|r|}
\hline & & Media_film_Animasi & Motivasi_Belajar \\
\hline $\mathrm{N}$ & & 28 & 28 \\
\multirow{2}{*}{ Normal Parameters } & Mean & 42.14 & 41.14 \\
& Std. Deviation & 7.382 & 4.309 \\
& Absolute & .329 & .181 \\
Most Extreme Differences & Positive & .144 & .150 \\
& Negative & -.329 & -.181 \\
Kolmogorov-Smirnov Z & & 1.742 & .959 \\
Asymp. Sig. (2-tailed) & & .005 & .317 \\
\hline
\end{tabular}

a. Test distribution is Normal.

b. Calculated from data.

Untuk meneliti motivasi belajar siswa pada mata pelajaran IPA di MI An-Nur Kota Cirebon Penulis menggunakan uji normalitas One-Sample KolmogorovSmirnov Test di atas, didapatkan nilai kolmogorov smirnov $Z$ adalah nilai 0.959 , karena nilai yang didapat melebihi nilai 0.05 , maka nilai signifikansinya normal. Dikarenakan memiliki nilai signifikansi yang normal, berarti respon siswa terhadap motivasi belajar siswa berasal dari popolasi berdistribusi normal.

\section{Rekapitulasi Prosentase Perhitungan Motivasi Belajar Siswa}

\begin{tabular}{|c|c|c|c|c|c|c|}
\hline \multirow{2}{*}{ No Item } & \multicolumn{5}{|c|}{ OPTION } & \multirow{2}{*}{ JUMLAH } \\
\cline { 2 - 6 } & 5 & 4 & 3 & 2 & 1 & \\
\hline 1 & $82 \%$ & $14 \%$ & $4 \%$ & $0 \%$ & $0 \%$ & $100 \%$ \\
\hline
\end{tabular}




\begin{tabular}{|c|c|c|c|c|c|c|}
\hline 2 & $35 \%$ & $50 \%$ & $7 \%$ & $4 \%$ & $4 \%$ & $100 \%$ \\
\hline 3 & $39 \%$ & $32 \%$ & $25 \%$ & $0 \%$ & $4 \%$ & $100 \%$ \\
\hline 4 & $21 \%$ & $25 \%$ & $32 \%$ & $18 \%$ & $4 \%$ & $100 \%$ \\
\hline 5 & $22 \%$ & $50 \%$ & $14 \%$ & $0 \%$ & $14 \%$ & $100 \%$ \\
\hline 6 & $60 \%$ & $32 \%$ & $4 \%$ & $4 \%$ & $0 \%$ & $100 \%$ \\
\hline 7 & $39 \%$ & $46 \%$ & $11 \%$ & $0 \%$ & $4 \%$ & $100 \%$ \\
\hline 8 & $43 \%$ & $39 \%$ & $14 \%$ & $0 \%$ & $4 \%$ & $100 \%$ \\
\hline 9 & $50 \%$ & $32 \%$ & $11 \%$ & $7 \%$ & $0 \%$ & $100 \%$ \\
\hline 10 & $39 \%$ & $43 \%$ & $7 \%$ & $11 \%$ & $0 \%$ & $100 \%$ \\
\hline Jumlah & $430 \%$ & $363 \%$ & $129 \%$ & $44 \%$ & $34 \%$ & $1000 \%$ \\
\hline Rata-Rata & $42 \%$ & $36.3 \%$ & $12.9 \%$ & $4.4 \%$ & $3.4 \%$ & $100 \%$ \\
\hline
\end{tabular}

Berdasarkan perhitungan angket motivasi belajar siswa di atas jumlah siswa yang menjawab sangat setuju dan setuju sebanyak 78,3\%. Hal ini membuktikan tingginya motivasi belajar siswa dalam pembelajara IPA di kelas V MI An-Nur Kota Cirebon. 


\section{Pengaruh Media Film Animasi Terhadap Motivasi Belajar Siswa Mata Pelajaran IPA di MI An-Nur Kota Cirebon}

Media film animasi merupakan media pembelajaran yang berbasis teknologi. Media film animasi memiliki kelebihan tersendiri dari media yang lainnya dalam menunjang proses pembelajaran IPA seperti dapat menjadikan materi pmbelajaran yang abstrak menjadi lebih konkrit, mengatasi ruang dan waktu dan dapat membantu mengatasi keterbatasan indra manusia.

Hal tersebut di tegaskan oleh pendapat. ( Kamriantiramli : 2011) dalam kelebihan media film animasi. Media animasi dapat membuat materi pelajaran yang abstrak menjadi lebih konkrit. Objek-objek atau materi misalnya dapat dijelaskan melalui media grafis berupa simbol simbol dan bagan. Demikian pula materi pelajaran yang rumit dapat disajikan secara lebih sederhana dengan bantuan media animasi. Misalnya materi yang membahas rangkaian katrol atau mesin dapat disederhanakan melalui bagan skema yang sederhana; Media animasi juga dapat mengatasi kendala keterbatasan ruang dan waktu. Sesuatu yang terjadi di luar ruang kelas, bahkan di luar angkasa dapat dihadirkan di dalam kelas melalui bantuan media animasi. Demikian pula beberapa peristiwa yang telah terjadi di masa lampau, dapat kita sajikan di depan siswa sewaktu waktu. Dengan media animasi pula suatu peristiwa penting yang sedang terjadi di benua lain dapat dihadirkan seketika di ruang kelas; dan media animasi dapat membantu mengatasi keterbatasan indera manusia. Obyek pelajaran yang terlalu kecil, terlalu besar atau terlalu jauh, dapat kita pelajari melalui bantuan media. Demikian pula obyek berupa proses/kejadian yang sangat cepat atau sangat lambat, dapat kita saksikan dengan jelas melalui media animasi, dengan cara memperlambat, atau mempercepat kejadian. Media animasi juga dapat menyajikan obyek pelajaran berupa benda atau peristiwa langka dan berbahaya ke dalam kelas. Peristiwa terjadinya gerhana matahari total yang jarang sekali terjadi, dapat disaksikan oleh siswa setiap saat melalui media rekaman. Terjadinya gunung meletus yang berbahaya dapat pula disaksikan siswa di kelas melalui media. 
Informasi pelajaran yang disajikan dengan media yang tepat akan memberikan kesan mendalam dan lebih lama tersimpan pada diri siswa.

Sedangkan untuk mengetahui besarnya pengaruh Media Film Animasi terhadap Motivasi Belajar maka peneliti menggunakan Analisis Model Summary ${ }^{\mathbf{b}}$

Model Summary

\begin{tabular}{|l|l|l|l|l|}
\hline Model & $R$ & $R$ Square & $\begin{array}{l}\text { Adjusted } \\
\text { Square }\end{array}$ & $\begin{array}{l}\text { Std. Error of the } \\
\text { Estimate }\end{array}$ \\
\hline 1 & $.496^{\mathrm{a}}$ & .246 & .217 & 3.812 \\
\hline
\end{tabular}

a. Predictors: (Constant), Media_Film_Animasi

b. Dependent Variable: Motivasi_Belajar

Berdasarkan analisis diatas besar pengaruh media film animasi dapat menggunakan angka R Square (koefisien determinasi) 0,246 x $100=24,6 \%$. Angka tersebut memiliki arti bahwa sebesar 24,6\% variabelitas motivasi belajar dipengaruhi oleh variable media film animasi. Dan sisanya sebesar 100-24,6 =75,4\% harus dijelaskan oleh faktor faktor lainya yang berasal dari luar model regresi ini.

Untuk menguji apakah model regresi tersebut sudah benar atau layak maka perlu dilakukan pengujian hubungan linieritas antara variable pengaruh media film animasi dengan motivasi belajar siswa.

Untuk keperluan analisis uji Anova a, diperlukan hipotesis sebagai berikut Ha : terdapat hubungan linier antara variable pengaruh media film animasi dan motivasi belajar siswa H0: tidak terdapat hubungan linier antara variable pengaruh media film animasi dan motivasi belajar siswa

\section{ANOVA $^{\mathrm{a}}$}

\begin{tabular}{|ll|l|l|l|l|l|}
\hline \multicolumn{2}{|l|}{ Model } & Sum of Squares & Df & Mean Square & F & Sig. \\
\hline & Regression & 123.581 & 1 & 123.581 & 8.504 & $.007^{\text {b }}$ \\
$1 \quad$ Residual & 377.847 & 26 & 14.533 & & \\
& & & & & & \\
& Total & 501.429 & 27 & & & \\
\hline
\end{tabular}



a. Dependent Variable: Motivasi_Belajar
b. Predictors: (Constant), Media_Film_Animasi

Berdasarkan tabel analisis anova b didapat nilai Sig sebesar 0,007 Karena lebih kecil 0,05 maka H0 ditolak dan Ha diterima maka terdapat hubungan linier antara variable pengaruh media film animasi dan motivasi belajar siswa di MI ANNUR Kota Cirebon.

\section{Penutup}

Berdasarkan penelitian yang dilakukan penulis di MI An-Nur Kota Cirebon tentang pengaruh media film animasi terhadap motivasi belajar siswa mata pelajaran IPA, dapat ditarik kesimpulan, penerapan dan penggunaan media film animasi di MI An-Nur Kota Cirebon sudah baik karena fasilitas yang sudah mendukung seprti sudah tersedianya proyektor dan alat pendukung lainnya dan cara guru dalam menggunakannya sudah baik. Hal tersebut tersebut terbukti dari hasil penelitian media film animasi rata - rata 84\%, motivasi belajar siswa pada mata pelajaran IPA di MI An-Nur Kota Cirebon mengalami peningkatan, hal tersebut dapat dilihat dari data nilai jawaban dari angket Motivasi belajar diperoleh rata - rata persentase yang menjawab 5 sebesar 42\%, menjawab 4 sebesar 36,5\%, yang menjawab 3 sebesar $12,9 \%$, yang menjawab 2 sebesar 4,4\%, dan yang menjawab 1 sebanyak 3,4\% dengan total responden sebanyak 28 siswa, pengaruh media film animasi terhadap motivasi belajar siswa mata pelajaran IPA di kelas tinggi MI An-Nur kota Cirebon dapat menggunakan angka R Square (koefisien determinasi) 0,246 x $100=24,6 \%$. Angka tersebut memiliki arti bahwa sebesar 24,6\% variabelitas motivasi belajar dipengaruhi oleh variable meda film animasi. Dan sisanya sebesar 100-24,6 =75,4\% harus dijelaskan oleh faktor faktor lainya yang berasal dari luar model regresi ini. Berdasarkan tabel analisis anova b didapat nilai Sig sebesar 0,007 Karena lebih kecil 0,05 maka H0 ditolak dan Ha diterima maka terdapat hubungan linier antara variable 
pengaruh media film animasi dan motivasi belajar siswa di MI AN-NUR Kota Cirebon .

\section{DAFTAR PUSTAKA}

Ahmadi,Abu dan Widodo. 2005. Strategi Belajar Mengajar. Bandung:CV Pustaka Setia.

Arikunto, Suharsimi.2013.Prosedur Penelitian Suatu Pendekatan Praktik.Jakarta: PT RinekaCipta . 2003. Pengantar Statistik Pendidikan.Jakarta: Rajawali Press.

.1998. Prosedur Penelitian Suatu Pendekatan Praktek. Jakarta:Rineka Cipta.

Artawan, Rudi. 2010. Pembelajaran biologi dengan menggunakan Media Animasi. . tersedia dalam http://biologinfo.blogspot.com/2010/07/pembelajaranbiologi-dengan-menggunakan.html diakses tanggal 17-04-2015 jam 03.55 wib

Ariyonso.2009.Penyusunan Hipotesis.Tersedia dalam https://ariyoso.wordpress.com/tag/membuat-hipotesis-statistik/ $\quad$ di unduh pada hari kamis 04/062015 jam 23:10 WIB

Asrori, Mohammad. 2009. Psikologi Pembelajaran, Bandung : CV Wacana Prima

Bisri,Hasan Cik. 2001. Penuntun Penyusunan Rencana Penelitian dan Penulisan Skripsi Bidang Ilmu Agama Islam. Jakarta: Raja Grafindo.

Bungsu, Ra Putra .2015. penggunaan media pembelajaran dalam proses belajar mengajar serta nilai dan manfaat media pembelajaran. Tersedia dalam https://www.academia.edu/3990310/penggunaan_media_pembelajaran _dalam_proses_belajar_mengajar_serta_nilai_dan_manfaat_media_pe mbelajaran diunduh tanggal 06/06/2015 jam 14:30 WIB

Darmawan, Deni.2011.Teknologi Pembelajaran.Bandung : PT. Remaja Rosdakarya

Djaali. 2008.Psikologi Pendidikan. Jakarta: PT. Bumi Aksara

Fauzi,Ahmad.1999.Psikologi Umum. Bandung:Pustaka Setia. 
Furoidah, Maya Fanny. 2009. Pengaruh Penggunaan Media Animasi Pembelajaran Terhadap Hasil Belajar Siswa pada Mata Pelajaran Biologi Kelas VII MTS Surya Buana Malang. Tersedia dalam . http://karyailmiah.um.ac.id/index.php/TEP/article/viewfile/4793/3397 diakses tanggal 17-04-2015 jam 03.55 wib

Gintings, Abdurrokhman.2012.Esensi Praktis Belajar DanPembelajaran.Bandung : Humaniora

Kamriantiramli,2011.Media Animasi Untuk Siswa. Tersedia dalam https://kamriantiramli.wordpress.com/tag/kelebihan-dan-kekuranganmedia-animasi/ Diunduh pada hari selasa 02/06/2015 jam 14.00 wib

Kasan, Tolib. 2009. Dasar-Dasar Pendidikan. Jakarta: Studia Press

Kumaidi dan Budi Manfaat. 2013. Pengantar Metode Statistika. Cirebon : Eduvision Publishing

Munadi, Yudhi.2010.Media Pembelajaran sebuah pendekatan baru.Jakarta: Gaung Persada Press

Nuryadin, Adin.2015. Pentingnya Pembelajaran IPA Di Sekolah Dasar. Tersedia dalam http://www.kompasiana.com/adin8118/pentingnyapembelajaran-ipa-di-sekolah-dasar 54f90eb1a33311f8478b49aa Diunduh pada hari selasa 02/06/2015 jam 14.00 wib.

Purwanto, Ngalim. 1997. Administrasi dan Supervisi pendidikan. Bandung: Remaja Rosda Karya.

Ridwan.2007.Belajar Mudah Penelitian untuk Guru-karyawan dan PenelitiPemula. Bandung: Alfabeta.

Sudjana, Nana.2010.Penilaian Hasil Proses Belajar Mengajar. Bandung: PTRemaja Rosda Karya.

Sudjana. 2004. Manajemen Program Pendidikan. Bandung:Falah Production.

Sudjiono,Anas. 2001. Statistic Pendidikan. Jakarta: Rajawali Press.

Sugiyono.2014.Metode Penelitian Pendidikan (Pendekatan Kuantitatif,Kualitatif,Dan $R \& D$. Bandung: Alfabeta 1996. Metodologi Penelitian Pendidikan. Bandung: Rajawali Press. 
Susiliana, Rudi dan Cepi Riana. 2008. Media Pembelajaran. Bandung : CV Wacana Prima

Syah, Muhibbin. 2004. Psikologi Pendidikan. Bandung: Remaja Rosdakarya.

Undang-Undang Guru dan Dosen (UU No. 14 tahun 2005) dan Standar Nasional Pendidikan (PP No. 19 tahun 2005)

Usman, Moh. Uzer dan Lilis Setiawati. 1998. Optimalisasi Kegiatan Belajar Mengajar, Bandung: PT. Remaja Rosda Karya.

Utami, Mundandar. 1992. Mengembangkan Bakat dan Kreativitas Anak Sekolah.Jakarta : Gramedia Widiasarana Indonesia.

Wahidin.2006. Metode Pendidikan Ilmu Pengetahuan Alam. Bandung: Sangga Buana.

Walpole, R.E. 1995. Pengantar Statistika (Edisi ke-3). Jakarta: Gramedia Pustaka Utama

Wijaya, Cece dan Rusyan Tabrani. 1991. Kemampuan Dasar guru dalam ProsesBelajar Mengajar. Bandung: Remaja Rosdakarya.

Wisudawati, Asih Widi dan Eka Sulistyowati. 2014. Metodologi Pembelajaran IPA. Jakarta: Bumi Aksara

Yamin, Sofyan dkk. 2011. Regresi dan Korelasi Dalam Genggaman Anda. Jakarta: Salemba Empat. 